\title{
Investigating the Effective Risks in Drinking Water Transport Pipelines Projects \\ (Case Study: Regional Water Company, Kermanshah Province)
}

\author{
Amin Kokabi ${ }^{1}$, Mehdi Komasi ${ }^{2}$, Nasser Sameti ${ }^{3}$ \\ ${ }^{1}$ Department of civil Engineering, \\ Borujerd Branch, Islamic Azad university, Borujerd, Iran \\ ${ }^{2}$ Department of civil Engineering, \\ Faculty of Engineering, University of Ayatollah Ozma Borujerdi, Borujerd, Iran. \\ komasi@abru.ac.ir \\ ${ }^{3}$ Department of civil Engineering, \\ Borujerd Branch, Islamic Azad university, Borujerd, Iran
}

\begin{abstract}
This study was carried out aimed to investigate risks affecting increased delays in drinking water pipeline transport projects (Case Study: Regional Water Company, Kermanshah Province). The statistical population in the present study consists of employees and contractors of Kermanshah regional water company. The interview was conducted with 25 people in order to collect information and conduct interviews about the characteristics of the model. The analytic hierarchy process (AHP) was performed. According to the results, among the identified areas related to the group of risks related to the considerations and geological conditions of the region, the risk related to the presence of faults in the area with a calculated weight of 0.19 and a trench bed settlement with a calculated weight of 0.13 and collision with clay soil in the path with the calculated weight of the 12/0 were selected as the most important effective factors. According to the results of the main criteria validation, among the five main criteria examined, the risk related to the conditions of piping with a weight of 0.47 was the most important indicators. After that, the risks related to the considerations and geological conditions of the region and the risks associated with access to the materials and materials needed for the project, each with a weight of 0.21, were considered as important factors in determining the risk of the Kermanshah water transport pipeline project.
\end{abstract}

Key words: Water transport pipeline project, Effective risk, AHP.

\section{Introduction}

The analysis of project risksare critical in important and high-risk projects such as water transport pipelines projectsdue tothe strategic importance of drinking water supply. Although civil engineers alone do not make critical decisions on these issues, but they are responsible for providing some specialized information to final decision makers. Surface waters and underground waters are considered as one of the main and key sources of drinking water.It is necessary for human life to know thatthe balance of water resources is threatened in quantitative and qualitative terms, in the last few decades, due to increasing population growth followed by an increase in the water needs of the country.One of the important parts of the water processesis the transfer from the source to the refinery and the transfer to the distribution network for consumption. This direction should be prevented by applying proper management and implementing the principled plans to increase the cost of transferring and constructing and constructing water transmission projects in different sectors.In this regard, it should be prevented from increasing the transfer and construction cost of water transfer projects in different sectors by proper management and implementation of substantiveplans. Each section of the project mustidentify the project risks within the project scope while aware of the activities and responses of other sectors. This study has investigated the effect of risk affecting increasing delays in drinking water transport pipelines projects in Kermanshah. 


\section{Background research}

Murianaac and Vizzini during a study investigateda Measurement and Quantitative Methods (MQM)for the project risk management evaluation and deal with it. They provided a definitive method for assessing and preventing project risks by determining the risk of the progress of work. They calculated the degree of the project risk through the Simple Average Weight (SAW) method. The practical application of their technique is related to the usual projects and the cases where the requirements planning must be defined at the planning stage and the deviation is detected at the development stage (Murianaac and Vizzini, 2017).

Erdogan et al., during a study entitled "Decisions in Construction Management": AHP and the Expert Choice Approach (ECA), investigated the contents of the construction projectsmanagement. The main problems of construction management have been identified and the possibility of solving them has been discussed. The decision making model in construction management is created using multiple methods and is used for real case studies. The AHP method and the Expert Choice Program were used for computations (Erdogan et al, 2017).

Zhang et al. introduced a risk assessment system for pipelines using a new method. They placedpipelinesin a river in the risk assessment, and considered them as a series system relative to the routing environment. They obtained a functional relationship between the total pipelines and the risk of each pipeline by combination of the system reliability theory with the method of mathematical induction. They developed risk acceptance criteria for risk analysis and pipeline maintenance manual (Zhang et al, 2019).

Hadisuwito and Hassan during a study entitled "Drought Index Calculation Methods Using Electre, Topsis, and Analytic Hierarchy Process", investigated several methods in drought calculation. They concluded that each method has specific variables for calculation, ie period, Data type, Formula complexity type, Usability, and results scale. In relation with the processing of seven techniques, the researcher monitors them using other techniques, such as ELECTRE, TOPSIS, and analytical hierarchy. In the final process, the resultsare compared in eth conclusion section. In summary, according o their results, the KBDI method is more recommended and TOPSIS is the best method.

Asschilean and Giurca during a studyinvestigatedthe choice of a method to review the selection of water distribution pipelines. They conducted a case study on the choice of the best technical solutions for the revitalization of water distribution pipelines in Klouj-nepapa, Romania. Five alternatives were investigated based on seven criteria. The criteria considered in the decision making include tube diameter, pipe length, duration of implementation, life span, pressure, price, and installation conditions, while the following methods are considered as the main options. They concluded that based on the highest global priority, Subline can be selected as a method of the rehabilitation of water distribution pipelines from asbestos cement pipes for ClujNapoca City, Romania. Aşchilean, 2018) and Giurca, Wu et al. investigated a modified three-phase framework for risk level assessment in China.

They used a method in the intuitionistic fuzzy environment for determining the weight of the index. They introduced a three-phase risk assessment model. First, they identified 18 risk factors and classified into four groups through a combination of project life cycle theory and Delphi methodology. According to their results, the financial problems, the clear division of responsibilities and commitments, the lack of operational experience, and the problems related to supplying materials and facilities, are considered as high-risk factors that should be resolved immediately ( $\mathrm{Wu}$ et al, 2019).

The goals which must be evaluated are often influenced by multiple factors simultaneously and decision makers should determine prioritiesdue to resource constraints, therefore there is a need for a comprehensive risk assessment of environmental projects in time. Guerin considered a number of aspects, including approval, costs, impacts of nature and community participation, comparison between expected and observed risks in a largescale photovoltaic project and focused on construction dangers (Guerin, 2017).

In order to evaluate the severity of construction projects more precisely, researchers investigated methods of coping with one-dimensionality and undesirable characteristics related to organizational risk factors through a ductal fuzzy number (Samantra et al., 2017). Fera et al., during a study entitled "prioritizing the risks in decision making for wind energy investment using the ANP", classified and prioritized the risks in an installation project for an energy wind initiative using ANP. Also, they investigated the risk factors for installation of wind machines. The specified risks relate mainly are related to the main stages of a project, including design, licensing, purchasing, making, commissioning, and maintenance over the limited lifetime of the device (Fera et al, 2017).

Khameneh et al. introduced a framework for the performance measurement of the project risk management system. Their study was carried out aimed to fill the gap by conducting a comprehensive study on identifying the performance indicators of the entire project risk management system and introduce a framework for the performance measurement of the system. The method used in this study was based on literature review and case studies in a project-based organization. The validity of this framework was evaluated by interviewing and reviewing risk management experts and combining their ideas (Khamenehet al, 2016) 
Kittur during a study investigated various methods, such as Simple Average Weight (SAW) method,weighing method and mechanism evaluation method of the enrichment assessment mechanism todetermine the optimal production of a particular day. The analytic hierarchy process (AHP) is usedto confirm the weight selection. The results of multi-criteria evaluation using the proposedmethods make possible the possibility of identification and evaluation of the optimal generationon a particular day. (Kittur, 2015).

\section{Method}

The research method and the method of research implementation, the statistical population and data collection tools and their analysis methods have been explained in this section. Expert selection software is used for data analysis. The work routine of the AHP model begins by identifying elements and decision making and prioritizing them. These elements include different ways of working and prioritizing features.

\subsection{Creating a hierarchical structure}

The most important part of the hierarchical analysis process is to convert the subject or issue under study into the hierarchical structure. If the project risks of the transport line in the Kermanshah regional water company are investigated, the goal is choosing the appropriate route for the water transport pipeline project. The criteria and sub-criteria include factors that cause differences in options. Validity of each location is measured in terms of criteria. In the AHP method, each criterion has a certain weight that should be used by the user in various ways. Also, each criterion can be divided into several smaller components and they can be compared with each other and they can be weighted.

\subsection{Study method}

The present study has first studies investigated the risks affecting selecting the risk of the Kermanshah water transport pipeline project. Then, it has tried to identify the features of a suitable model for project risk selection. This is done through open-ended questionnaires that are distributed among project staff and contractors, as well as using library studies. Then, the model has been designed. This design is based on the identification and determination of risks that are considered as a suitable measure for the performance measurement of employees and contractors who are working for the Kermanshah regional water company. This identification was done using library studies as well as technical expert opinion. After identifying the indicators using the hierarchical analysis process (AHP), these indicators are weighted according to their importance degree. Identified risks and determined weights are measured using questionnaires distributed among the experts

\subsection{Sample and statistical population}

The statistical population consists of employees and contractors of Kermanshah regional water company. The informant population includes technical staff and experts. Expert opinions have been used in different parts of the project in order to collect data. 25 people of project staff who were selected from project personnel and technical staff of the consultant engineer and client and contractor staff in order to collect information and conduct interviews about the features of the model. In this study, the Delphi technique has been used, during this technique, some questions are answered from experts and qualified individuals.

\subsection{Data collection method}

In general, an opportunity was provided for interviewing 25 specialists during a month. In interviews after giving explanations about the subject and objective of the study, they were asked to answer the following question:

\section{$\checkmark \quad$ What are the risks affecting drinking water transport pipeline projects in Kermanshah Regional WaterCompany?}

It should be noted that this interview was conducted in a semi-structured and semi-directed manner. The results of these interviews are summarized and close answers are integrated and presented in Table 1.

\section{5. model}

\subsubsection{Determination of the indicators and weighting them}

After data collection from the experts and analyzing them, the introduced indicators are classified into five main categories according to the content and subject matter discussed, and the results are listed in Table 1. Table 1Indicators grouping after classification results are listed in Table 1. 
Table 1- Indicators grouping after classification

\begin{tabular}{|c|l|c|c|}
\hline row & \multicolumn{1}{|c|}{ The classify allocated with the index expressed } & $\begin{array}{c}\text { Number of } \\
\text { subscript indices }\end{array}$ & $\begin{array}{c}\text { Frequency of } \\
\text { Indicator Design by } \\
\text { Experts }\end{array}$ \\
\hline 1 & Risks of geological conditions of the region & 40 & 25 \\
\hline 2 & Risk of piping conditions & 124 & 25 \\
\hline 3 & Risks of access to materials needed for the project & 41 & 25 \\
\hline 4 & $\begin{array}{l}\text { Risks of time considerations on time to advance } \\
\text { piping operations }\end{array}$ & 8 & 21 \\
\hline 5 & Risks of piping procedures & 5 & 14 \\
\hline
\end{tabular}

\section{Results}

In order to determine the weight of the indicators listed in each of tables 2 to 6 , the weight of each indicator is normalized and its significance is determined by considering the number of questions and indicators identified in the subset, as well as the number of frequency of their design is determined by the experts.

Therefore, according to the following formula for each of the indices of considerations and indices of geological conditions of the region, indices related to foundation, resource access indexes, indexes related to hydraulic structures, as well as indicators related to structural execution steps are done as follows.

Table 2- Areas identified related to the risks group related to the considerations and geological conditions of the region

\begin{tabular}{|c|c|c|c|c|}
\hline row & $\begin{array}{c}\text { The classify allocated with the index } \\
\text { expressed }\end{array}$ & $\begin{array}{c}\text { Number of } \\
\text { identified } \\
\text { risks }\end{array}$ & $\begin{array}{c}\text { Frequency of } \\
\text { Indicator Design } \\
\text { by Experts }\end{array}$ & $\begin{array}{c}\text { Calculated } \\
\text { weight } \\
\text { (Normalized) }\end{array}$ \\
\hline 1 & The presence of faults in the region & 4 & 20 & 0.19 \\
\hline 2 & trench bed settlement & 3 & 18 & 0.13 \\
\hline 3 & collision with clay soil in the route & 3 & 17 & 0.12 \\
\hline 4 & Weak rock mass & 2 & 16 & 0.08 \\
\hline 5 & Rainfall and catchment area & 3 & 15 & 0.11 \\
\hline 6 & Graining Soil Route & 2 & 12 & 0.06 \\
\hline 7 & Continuous Rock Mechanics Tests & 3 & 8 & 0.06 \\
\hline 8 & High groundwater level & 4 & 8 & 0.08 \\
\hline 9 & Landslide & 1 & 6 & 0.02 \\
\hline 10 & Seismic testing & 1 & 6 & 0.02 \\
\hline 11 & wrinkle & 2 & 5 & 0.11 \\
\hline 12 & seismic Hazards & 9 & 5 & 0.01 \\
\hline 13 & Graining and route soil type & 3 & 2 & \\
\hline
\end{tabular}


Table 3- Identified areas relating to risks relating to piping conditions

\begin{tabular}{|c|c|c|c|c|}
\hline row & $\begin{array}{l}\text { The classify allocated with the index } \\
\text { expressed }\end{array}$ & $\begin{array}{l}\text { Number of } \\
\text { identified } \\
\text { risks }\end{array}$ & $\begin{array}{c}\text { Frequency of } \\
\text { Indicator Design } \\
\text { by Experts }\end{array}$ & $\begin{array}{c}\text { Calculated } \\
\text { weight } \\
\text { (Normalized) }\end{array}$ \\
\hline 1 & The status of soil layers & 10 & 21 & 0.11 \\
\hline 2 & Rackfall within the trench & 16 & 18 & 0.15 \\
\hline 3 & Safety of machinery and equipment & 5 & 15 & 0.05 \\
\hline 4 & Soil compaction of piping bed & 9 & 13 & 0.06 \\
\hline 5 & Executive staff expertise & 10 & 11 & 0.06 \\
\hline 6 & Experiments needed & 9 & 10 & 0.05 \\
\hline 7 & for determination of pipe & 5 & 14 & 0.04 \\
\hline 8 & specifications & 7 & 16 & 0.06 \\
\hline 9 & The experiments needed for & 10 & 22 & 0.12 \\
\hline 10 & joints and sealing pipe & 7 & 20 & 0.08 \\
\hline 11 & Pipeline route warning signs & 7 & 15 & 0.06 \\
\hline 12 & $\begin{array}{l}\text { Reporting and reviewing manpower } \\
\text { events and equipment failures }\end{array}$ & 4 & 11 & 0.02 \\
\hline 13 & Observing safety and rules & 5 & 24 & 0.08 \\
\hline 14 & $\begin{array}{l}\text { Negotiation and inspection on the route } \\
\text { regulations }\end{array}$ & 3 & 3 & 0.01 \\
\hline 15 & Safety of materials and equipment & 4 & 7 & 0.01 \\
\hline 16 & Resource management & 1 & 17 & 0.01 \\
\hline 17 & $\begin{array}{l}\text { The use of personal protective } \\
\text { equipment }\end{array}$ & 7 & 7 & 0.03 \\
\hline
\end{tabular}

Table (4)- Areas identified in the risk group related to access to materials needed for the project

\begin{tabular}{|c|l|c|c|c|}
\hline Row & \multicolumn{1}{|c|}{ Number of identified risks } & $\begin{array}{c}\text { Number of } \\
\text { identified } \\
\text { risks }\end{array}$ & $\begin{array}{c}\text { Frequency of } \\
\text { Indicator Design by } \\
\text { Experts }\end{array}$ & $\begin{array}{c}\text { Calculated } \\
\text { weight } \\
\text { (Normalized) }\end{array}$ \\
\hline 1 & $\begin{array}{l}\text { Supply of pipeline inspection and } \\
\text { inspection equipment }\end{array}$ & 6 & 21 & 0.19 \\
\hline 2 & Supply and purchase of pipes & 11 & 21 & 0.35 \\
\hline 3 & Purchase and storage of joints & 2 & 16 & 0.08 \\
\hline 4 & Use of the sandy soil & 4 & 16 & 0.01 \\
\hline 5 & Periodic tune-up drilling tools & 5 & 12 & 0.09 \\
\hline 6 & $\begin{array}{l}\text { Machine efficiency and easy access to } \\
\text { peripherals }\end{array}$ & 6 & 12 & 0.12 \\
\hline 7 & Foundation quality and soil compaction & 6 & 12 & 0.12 \\
\hline 8 & $\begin{array}{l}\text { Accessories needed for pipeline testing } \\
\text { equipment }\end{array}$ & 1 & 11 & 0.04 \\
\hline
\end{tabular}


Table 5- Areas identified in the risk group of the risks related to considerations of the time to advance piping operations

\begin{tabular}{|c|l|c|c|c|}
\hline Row & \multicolumn{1}{|c|}{ Number of identified risks } & $\begin{array}{c}\text { Number of } \\
\text { identified } \\
\text { risks }\end{array}$ & $\begin{array}{c}\text { Frequency of } \\
\text { Indicator Design } \\
\text { by Experts }\end{array}$ & $\begin{array}{c}\text { Calculated } \\
\text { weight } \\
\text { (Normalized) }\end{array}$ \\
\hline 1 & Long-term stop during piping operations & 1 & 19 & 0.14 \\
\hline 2 & $\begin{array}{l}\text { Clearing the route from the plants and the } \\
\text { roots of the trees }\end{array}$ & 1 & 18 & 0.14 \\
\hline 3 & Adjusting the slope of the trench floor & 1 & 17 & 0.03 \\
\hline 4 & $\begin{array}{l}\text { Bed construction and pouring and } \\
\text { compacting the soil of the bed }\end{array}$ & 1 & 18 & 0.14 \\
\hline 5 & Embankment after piping & 1 & 17 & 0.13 \\
\hline 6 & Implementation of connections & 1 & 15 & 0.11 \\
\hline 7 & Time of excavation and embankment & 1 & 15 & 0.11 \\
\hline 8 & Piping time & 1 & 14 & 0.11 \\
\hline
\end{tabular}

Table (6)- Areas identified in the group of the risks related to executive steps of piping

\begin{tabular}{|l|l|c|c|c|}
\hline Row & \multicolumn{1}{|c|}{$\begin{array}{c}\text { The group allocated with the index } \\
\text { expressed }\end{array}$} & $\begin{array}{c}\text { Number of } \\
\text { identified } \\
\text { risks }\end{array}$ & $\begin{array}{c}\text { Frequency of } \\
\text { Indicator Design } \\
\text { by Experts }\end{array}$ & $\begin{array}{c}\text { Calculated } \\
\text { weight } \\
\text { (Normalized) }\end{array}$ \\
\hline 1 & Cleaning the project site & 1 & 12 & 0.24 \\
\hline 2 & $\begin{array}{l}\text { The power required to drill a trench in } \\
\text { different areas }\end{array}$ & 1 & 14 & 0.28 \\
\hline 3 & Boreholes of soil route identification & 1 & 10 & 0.2 \\
\hline 4 & Installation of joints and testing & 1 & 14 & 0.28 \\
\hline
\end{tabular}

\subsection{Investigating the validity of criteria and weights related to them}

A questionnaire was developed and distributed among the experts after calculating the indicators in order to measure the validity of the weights obtained, 25 of experts answered the questions. The results of the review of technical expert opinions for the main criteria are listed in Table 6.

Table 7: Results of Validation of Main Criteria

\begin{tabular}{|l|c|c|}
\hline The group allocated with the index expressed & $\begin{array}{c}\text { Average allocated } \\
\text { rating }\end{array}$ & Index weight \\
\hline $\begin{array}{l}\text { Risks related to considerations and geological conditions the of } \\
\text { Area }\end{array}$ & 4 & 0.21 \\
\hline Risks related to piping conditions & 9 & 0.47 \\
\hline Access risks To Materials and Materials Case Need Project & 4 & 0.22 \\
\hline $\begin{array}{l}\text { Risks related to considerations of the time to advance } \\
\text { intubation operations }\end{array}$ & 1 & 0.05 \\
\hline Risks related to executive steps of piping & 1 & 0.05 \\
\hline
\end{tabular}

4.2. Selection of measures affecting effective risks in increasing delays in the projects water transport pipelines drinking of Kermanshah regional water company through the hierarchical analysis process

In the next phase, after the main criteria and sub-criteria were determined, a hierarchical model is determined. Figure 1, shows a hierarchical analysis model of risks affecting drinking water pipelines projects of Kermanshah regional water company. The final model is determined after determining the purpose and identifying the main criteria and the sub criteria. In this analysis, according to the score obtained from the designed checklist, the scores obtained from each index are compared to each other and, in the end, necessary decisions are made about the effective risks in increasing the delays in the water transport pipelines projects of the Kermanshah regional through the process of hierarchical analysis. 


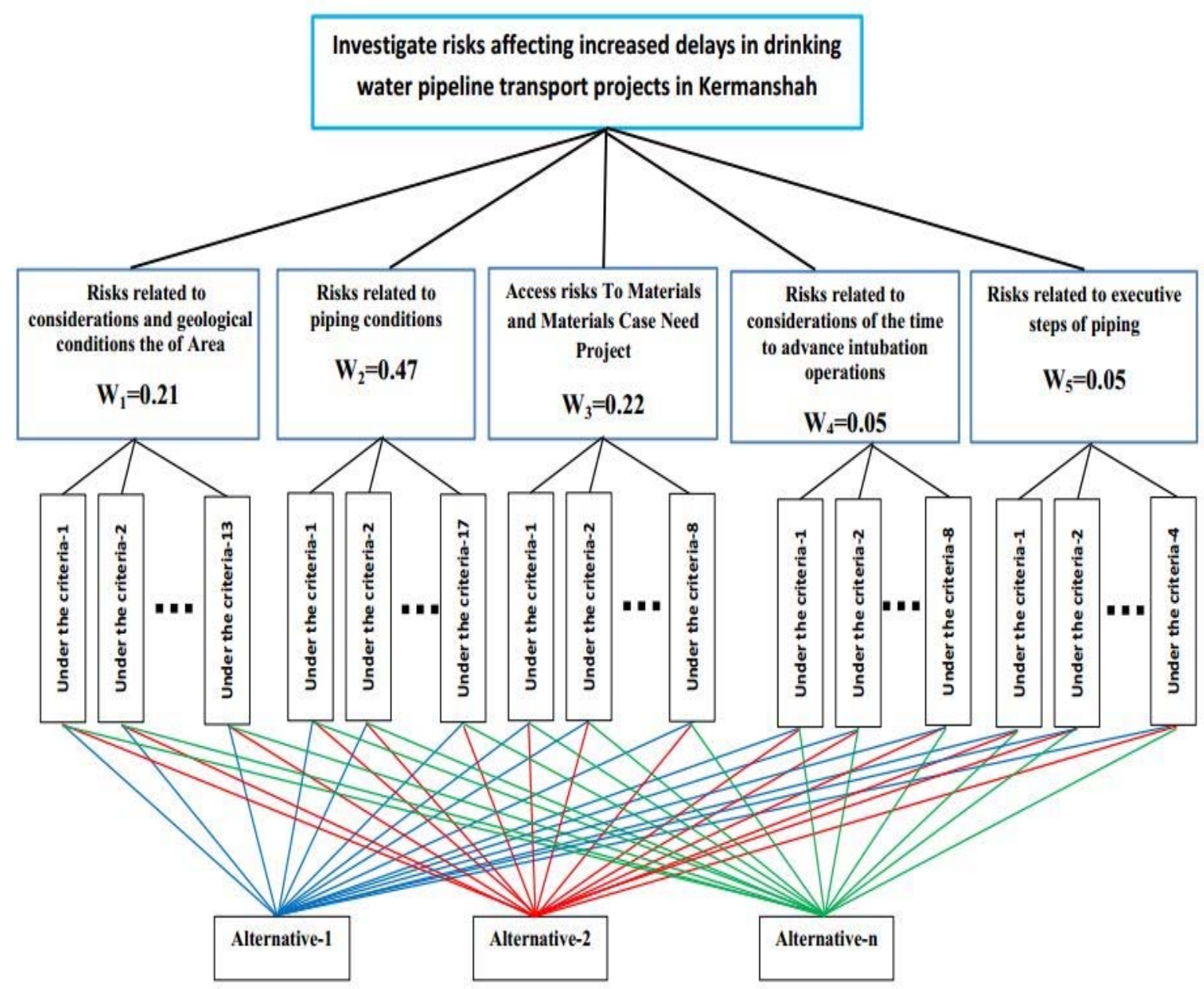

Figure 1- Hierarchical analysis Model of Risks Affecting Drinking Water Transport Pipelines Projects in Kermanshah Regional Water Company

Given that the identified risks in each area follow each other's specific criteria independently, it can be concluded that the identified main risks are also independent.

\section{Conclusion}

The present study has investigated the risks affecting drinking water transport pipelines projects of Kermanshah regional water company. The results of this thesis are:

$>$ Among the identified risks related to the group of risks related to the considerations and geological conditions of the region, the presence of the fault in the area with a calculated weight of 0.19 and a trench bed arrangement with a calculated weight of 0.13 and collision with clay soil in the route with the calculated weight of the 0.12 were selected as the most important effective factors.

$>$ Risks related to the trenching intubation piping conditions with a calculated weight of 0.12 , and the safety of machinery and equipment with a calculated weight of 0.15 and rockfall within the trench with a calculated weight of 0.11 were selected as the most important factors.

$>$ The risks related to access to the materials required for the supply and purchase of pipe with a calculated weight of 0.35 , and supply of testing and inspection equipment with a calculated weight of 0.19 , and the efficiency of machines with a calculated weight of 0.11 and easy access to equipment with weight of 0.11 was selected as the most important factors.

$>$ About the risks related to the considerations of the time to advance piping operations, long-term stopping of piping and bed construction operations, and pouring and compacting the bedding soil with a calculated weight of 0.14 , and adjusting the slope of the trench floor and embankment after the piping with a weight of 0.13 were selected as main and effective parameters in this section.

$>$ About the risks related to the implementation of the piping process, the power required for drilling trenches in different lands with a weight of 0.28 and installation of joints and testing with a weighing 0.28 , and cleaning the project site with a calculated weight of 0.24 , were selected as the most important factors in this selection. 
According to the results of the main criteria validation, among the five main criteria examined, the risks related to piping conditions with a weight of 0.47 was selected as the most important index. After that, the risks related to the considerations and geological conditions of the region and the risks associated with access to the materials and materials needed for the project, each with a weight of 0.21 , were selected as the important factors in determining the risk of the Kermanshah transport line project.

\section{References}

[1] Muriana, Cinzia, and Giovanni Vizzini. "Project risk management: A deterministic quantitative technique for assessment and mitigation." International Journal of Project Management 35, no. 3 (2017): 320-340.

[2] Erdogan, Seyit Ali, Jonas Šaparauskas, and Zenonas Turskis. "Decision making in construction management: AHP and expert choice approach." Procedia engineering 172 (2017): 270-276.

[3] Zhang, Peng, Guojin Qin, and Yihuan Wang. "Risk Assessment System for Oil and Gas Pipelines Laid in One Ditch Based on Quantitative Risk Analysis." Energies 12, no. 6 (2019): 981.

[4] Hadisuwito, A. S., and F. H. Hassan. "Selection Drought Index Calculation Methods Using Electre, Topsis, and Analytic Hierarchy Process." International Journal of Engineering \& Technology 7, no. 4.44 (2018): 188-193.

[5] Așchilean, Ioan, and Ioan Giurca. "Choosing a Water Distribution Pipe Rehabilitation Solution Using the Analytical Network Process Method." Water 10, no. 4 (2018): 484.

[6] Wu, Yunna, Yiming Ke, Jing Wang, Lingwenying Li, and Xiaoshan Lin. "Risk assessment in photovoltaic poverty alleviation projects in China under intuitionistic fuzzy environment." Journal of Cleaner Production 219 (2019): 587-600.

[7] Guerin, T.F., 2017. Evaluating expected and comparing with observed risks on alarge-scale solar photovoltaic construction project: a case for reducing theregulatory burden. Renew. Sustain. Energy Rev. 74, 333e348

[8] Samantra, C., Datta, S., Mahapatra, S.S., 2017. Fuzzy Based Risk Assessment Modulefor Metropolitan Construction Project: an Empirical Study. Engineering Applications of Artificial Intelligence.

[9] Fera, M., R. Macchiaroli, F. Fruggiero, and A. Lambiase. "Risks Prioritization in Decision Making for Wind Energy Investments using Analytic Network Process (ANP)." Int. J. Appl. Eng. Res 12 (2017): 2567-2574.

[10] Khameneh, Amir-Hossein, Alireza Taheri, and Mahmood Ershadi. "Offering a framework for evaluating the performance of project risk management system." Procedia-Social and Behavioral Sciences 226 (2016): 82-90.

[11] Javeed Kittur ".Optimal Generation Evaluation using SAW, WP,AHP and PROMETHEE Multi - Criteria DecisionMaking Techniques." EEE [nterational Conference on Technological Advancements in Power \& Energy.2015. 